\title{
Pengaruh Orientasi Etika Terhadap Komitmen Profesional dan Implikasinya pada Kualitas Audit
}

\author{
Oleh : \\ Indah Fitriani,SE.,M.Ak.,Ak.CA \\ Hary Rahmat Hidayat
}

\begin{abstract}
Abstrak
Tujuan penelitian dilakukan untuk mengetahui: (i)Pengaruh orientasi etika terhadap komitmen profesional; (ii)Pengaruh orientasi etika terhadap kualitas audit; (iii) Pengaruh komitmen profesional terhadap kualitas audit; (iv) Pengaruh orientasi etika terhadap komitmen profesional dan implikasinya pada kualitas audit.

Populasi dalam penelitian ini adalah auditor Badan Pemeriksa Keuangan Jawa Barat di kota Bandung. Variabel independen dalam penelitian ini adalah orientasi etika dan komitmen profesional, sedangkan variabel dependennya adalah kualitas audit. Metode yang digunakan dalam penelitian ini adalah metode deskriptif dan verifikatif. Untuk metode pengumpulan data menggunakan metode kuesioner. Teknik analisis yang digunakan adalah path analysis (analisis jalur), pengujian hipotesis menggunakan teknik korelasi product moment, data yang digunakan adalah data primer.

Berdasarkan hasil penelitian didapatkan bahwa: (i)Orientasi etika memiliki pengaruh positif terhadap komitmen profesional sebesar 50,7\%,; (ii) Orientasi etika memiliki pengaruh positif terhadap kualitas audit sebesar 52,8\%; (iii)Komitmen profesional memiliki pengaruh positif terhadap kualitas audit sebesar 52,7\%; (iv) Orientasi etika memiliki pengaruh positif terhadap komitmen profesional dan memiliki implikasi pada kualitas audit dengan pengaruh langsung sebesar $18,5 \%$
\end{abstract}

\section{Kata Kunci: Orientasi Etika, Komitmen Profesional, Kualitas Audit}

\section{Latar Belakang}

Kasus fraud terutama korupsi di Indonesia sangatlah tinggi. Hal itu dapat dilihat pada Corruption Perception Index yang menyebutkan bahwa pada tahun 2012, Indonesia mendapatkan IPK 3,0 dan berada pada urutan 100 bersama Argentina, Madagaskar, Meksiko, dan delapan Negara lain dengan IPK yang sama. Selain korupsi, masalah fraud yang sering terjadi di pemerintahan daerah adalah penyimpangan atas laporan keungan atau Financial Statement Fraud. Hal ini sesuai dengan pernyataan BPK yang dikutip dari LENSAINDONESIA.COM:

"Badan Pemeriksa Keungan RI melaporkan hasil audit pada semester II 2011 terhadap Laporan Keungan Pemerintah Daerah (LKPD), menemukan12.612 kasus penyimpangan. Akibatnya terjadi kebocoran negara atau negara mengalami kerugian, potensi kerugian, dan kekurangan senilai Rp 20,25 triliun.”

Pernyataan diatas menunjukan bahwa selain korupsi, masalah Financial Statement Fraud menjadi hal yang sering terjadi di pemerintahan dan menyebabkan kerugian negara dengan jumlah yang sangat besar. Salah satu fenomena yang terjadi di BPK RI Jawa Barat yaitu pada tahun 2010. Auditor BPK Jawa Barat ditetapkan menjadi tersangka

Jadi untuk mendapatkan kualitas audit yang baik dibutuhkan akuntabilitas yang merupakan dorongan psikologi sosial yang dimiliki seseorang untuk menyelesaikan 
kewajibannya yang akan dipertanggungjawabkan kepada lingkungannya. Dalam melaksanakan tanggungjawabnya sebagai profesional, setiap auditor harus senantiasa menggunakan pertimbangan moral dan mempunyai komitmen profesional dalam semua kegiatan yang dilakukannya.

Dalam melakukan kewajiban sebagai profesi kita harus mengetahui dahulu peraturan dan etika yang telah ditetapkan agar kita tidak melakukan kesalahan/ melanggar kode etik yang ada. Karena itulah diperlukan orientasi etika bagi para profesi untuk menjalankan tugas dan tanggungjawabnya.

\section{Rumusan Masalah}

Rumusan masalha yang dikemukakan adalah:

1. Apakah orientasi etika berpengaruh terhadap komitmen profesional

2. Apakah orientasi etika berpengaruh terhadap kualitas audit.

3. Apakah komitmen profesional berpengaruh terhadap kualitas audit.

4. Apakah orientasi etika berpengaruh terhadap komitmen profesional dan implikasinya pada kualitas audit.

\section{Tinjauan Teori dan Kerangka Pemikiran}

Menurut Arens (2008:98) "etika secara garis besar dapat di definisikan sebagai serangkaian prinsip atau nilai moral. Setiap orang memiliki rangkaian nilai seperti itu, meskipun kita memperhatikan atau tidak memperhatikannya secara eksplisit”. Skala komitmen profesional (Aranya dan Feris, 1984) memfokuskan pada kemauan auditor untuk mengambil tindakan keuntungan profesi dan pada kesamaan nilai auditor.

Maka dapat disimpulkan orientasi etika akuntan berpengaruh terhadap komitmen profesional. Seorang auditor yang memiliki orientasi etika lebih tinggi cenderung untuk dapat mengenali isu-isu etika dengan lebih teliti, membuat keputusan yang menyangkut etika dengan lebih baik, lebih berhati-hati ketika menghadapi dilema etika, berusaha menerapkan standar profesi lebih konsisten dan terakhir adalah melakukan pekerjaan profesionalnya dengan objektif.

Menurut Arens (2008:98) "etika secara garis besar dapat di definisikan sebagai serangkaian prinsip atau nilai moral. Setiap orang memiliki rangkaian nilai seperti itu, meskipun kita memperhatikan atau tidak memperhatikannya secara eksplisit”.

Menurut De Angelo (1981) mendefinisikan kualitas audit sebagai probabilitas dimana auditor akan menemukan dan melaporkan pelanggaran yang ada dalam sistem akuntansi klien. Adapun kemampuan untuk menemukan salah saji yang material dalam laporan keuangan perusahaan tergantung dari kompetensi auditor sedangkan kemauan untuk melaporkan temuan salah saji tersebut tergantung pada independensinya. Oleh karena itu orientasi etika memiliki dampak positif terhadap kualitas audit.

Komitmen profesional dapat didefinisikan sebagai: 1. Sebuah kepercayaan dan dukungan terhadap tujuan dan nilai organisasi dan/atau profesi, 2. Sebuah keinginan untuk menggunakan usaha yang sungguh-sungguh guna kepentingan organisasi dan/atau profesi, 3. Keinginan untuk memelihara keanggotaan dalam organisasi dan/atau profesi (Aranya dan Feris, 1984).

Untuk memperoleh hasil dari praktek audit, komitmen profesional merupakan pendorong utama untuk menentukan independensi audit dan kualitas audit. Komitmen profesional dibentuk selama proses sosialisasi dan dihadapi oleh individu melalui pengalaman profesional (Lu et al., 2007). Komitmen profesional mempunyai kekuatan untuk menstabilkan yang berperan untuk mempertahankan arah perilaku dengan kondisi pengharapan. Terdapat 4 aspek yang berkaitan dengan komitmen profesional, yaitu kesediaan untuk membuat usaha, mempertahankan 
keanggotaan, kepercayaan dalam tujuan, dan penilaian dalam melanjutkan suatu karir. Menurut teori kepatuhan, kemauan untuk patuh berasal dari kewajiban moral dan pengaruh sosial didasarkan pada legitimasi yang dirasakan dari pemerintah yang dibebankan dengan menerapkan peraturan (Indah 1998). Hal tersebut akan mendorong aparat pemerintahan untuk menyusun laporan keuangan sesuai dengan undang-undang yang berlaku serta sesuai dengan standar akuntansi pemerintahan sehingga terciptanya nilai informasi laporan keuangan yang berkualitas.

Auditor dengan komitmen profesional yang tinggi cenderung menghasilkan manfaat dan keuntungan bagi dirinya sendiri dan lembaga profesionalnya. Komitmen profesional diterapkan dalam rangka meningkatkan kualitas audit di pasar audit dan lingkungan yang kompetitif. Oleh karena itu, komitmen profesional memiliki dampak positif terhadap kualitas audit.

Aranya dan Ferris (1984) menjelaskan mengenai karakteristik dari komitmen profesional sebagai berikut:

1. Identifikasi adalah penerimaan tujuan, kesamaan nilai-nilai pribadi dengan profesi, serta kebanggaan menjadi bagian dari profesinya.

2. Keterlibatan merupakan kesediaan untuk bekerja dan berusaha untuk sebaik mungkin bagi profesinya.

3. Loyalitas adalah suatu ikatan emosional, keinginan untuk tetap menjadi bagian dari anggota profesi.

Forsyth (1980) berpendapat bahwa orientasi etika digerakkan oleh dua karakteristik yaitu idealisme dan relativisme. Idealisme berhubungan dengan tingkat dimana individual percaya bahwa konsekuensi yang diinginkan (konsekuensi positif) tanpa melanggar kaidah moral. Sikap idealis juga diartikan sebagai sikap tidak memihak dan terhindar dari berbagai kepentingan. Seorang akuntan yang tidak bersikap idealis hanya mementingkan dirinya sendiri agar mendapat fee yang tinggi dengan meninggalkan sikap independensi. Di sisi lain, sikap relativisme secara implisit menolak moral absolut pada perilakunya.

Seorang auditor yang memiliki orientasi etika lebih tinggi cenderung untuk dapat mengenali isu-isu etika dengan lebih teliti, membuat keputusan yang menyangkut etika dengan lebih baik, lebih berhati-hati ketika menghadapi dilema etika, berusaha menerapkan standar profesi lebih konsisten dan terakhir adalah melakukan pekerjaan profesionalnya dengan objektif.

Auditor mempunyai peranan penting dalam pengesahan laporan keuangan suatu perusahaan. Sehingga auditor harus menghasilkan audit yang berkualitas sehingga dapat mengurangi ketidakselarasan yang terjadi antara pihak manajemen dan pemilik (Elfarini, 2007). Oleh karena itu orientasi etika memiliki dampak positif terhadap kualitas audit.

Untuk memperoleh hasil dari praktek audit, komitmen profesional merupakan pendorong utama untuk menentukan independensi audit dan kualitas audit. Komitmen profesional dibentuk selama proses sosialisasi dan dihadapi oleh individu melalui pengalaman profesional (Lu et al., 2007). Komitmen profesional mempunyai kekuatan untuk menstabilkan yang berperan untuk mempertahankan arah perilaku dengan kondisi pengharapan. Terdapat 4 aspek yang berkaitan dengan komitmen profesional, yaitu kesediaan untuk membuat usaha, mempertahankan keanggotaan, kepercayaan dalam tujuan, dan penilaian dalam melanjutkan suatu karir.

Auditor dengan komitmen profesional yang tinggi cenderung menghasilkan manfaat dan keuntungan bagi dirinya sendiri dan lembaga profesionalnya. Komitmen profesional diterapkan dalam rangka meningkatkan kualitas audit di pasar audit dan lingkungan yang kompetitif. Oleh karena itu, komitmen profesional memiliki dampak positif terhadap kualitas audit. 
Dari uraian diatas dapat disimpulkan bahwa baik atau buruknya kualitas audit didapat tergantung dari komitmen seorang auditor yang bertanggung jawab atas laporan keuangan tersebut, semakin baik komitmen seorang auditor maka semakin kecil fraud atau salah saji yang terjadi. Agar seorang auditor dapat memiliki komitmen profesional dia harus memiliki orientasi etika yang tinggi pula, karena dengan memiliki orientasi etika yang tinggi maka komitmen seorang auditor pun akan semakin kuat. Karena itulah orientasi etika memiliki pengaruh terhadap komitmen profesional dan memiliki implikasi pada kualitas audit.

Maka kerangka pemikirannya dapat digambarkan seperti berikut:

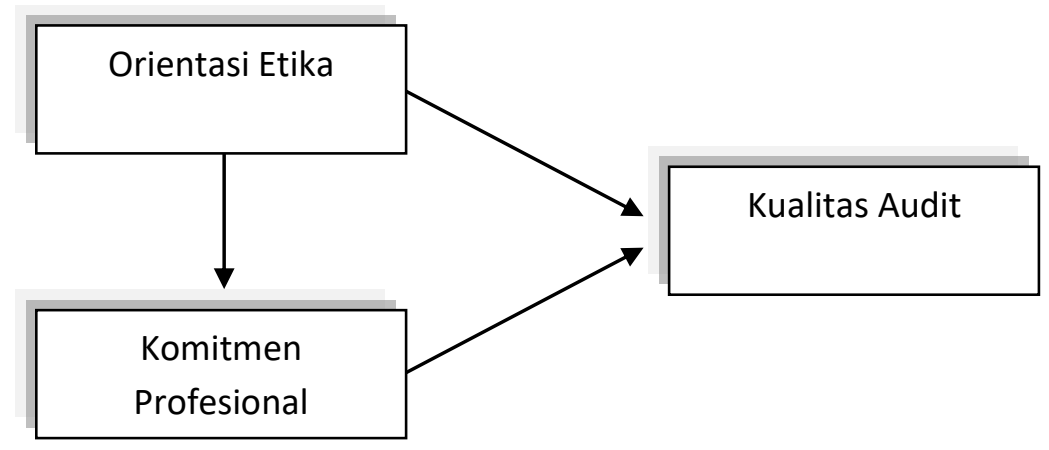

\section{Hipotesis}

1. Orientasi etika berpengaruh terhadap komitmen profesional.

2. Orientasi etika berpengaruh terhadap kualitas audit.

3. Komitmen profesional berpengaruh terhadap kualitas audit.

4. Orientasi etika berpengaruh terhadap komitmen profesional dan memiliki implikasi pada kualitas audit.

\section{Metodologi Penelitian}

Objek dalam penelitian ini adalah orientasi etika, komitmen profesional dan kualitas audit di BPK RI Jawa Barat yang berada di Kota Bandung.

Metode ini menggunakan metode penelitian deskriptif dan verifikasi. Data penelitian yang dibutuhkan adalah data primer dalam bentuk persepsi responden (subjek) penelitian. Pengambilan data menggunakan observasi langsung dan instrumen yang digunakan adalah kuesioner (angket). Teknik yang digunakan untuk menganalisis data dalam penelitian ini adalah dengan menggunakan metode kuantitatif. Metode analisis data yang digunakan untuk menguji dalam penelitian ini yaitu Path Analysis.

\section{Populasi dan Sample Penelitian}

Populasi dalam penelitian ini adalah auditor di BPK RI Jawa Barat yang berjumlah 100 orang. Metode pengambilan sampel yang digunakan dalam penelitian ini adalah Probability sampling yaitu teknik pengambilan sampel yang memberikan peluang yang sama bagi setiap unsur (anggota) populasi untuk dipilih menjadi anggota sampel. Teknik pengambilan sampel yang digunakan adalah simple random sampling., yaitu teknik pengambilan sampel apabila semua populasi digunakan sebagai sampel, dengan menggunakan rumus Slovin sehingga sampel yang diambil pada penelitian ini sebanyak 50 orang. 


\section{Teknik Analisis Data}

\section{Uji Validitas dan Reliabilitas}

Untuk melihat validitas masing-masing instrumen yang digunakan, peneliti menggunakan koefisien Factor Analysis. Suatu instrumen dikatakan valid jika memiliki nilai koefisien validitasnya lebih besar dari 0,3 . Untuk mengetahui bahwa pernyataan yang digunakan dalam instrumen reliabel, maka digunakan Cronbach Alpha. Instrumen dikatakan valid jika memiliki nilai Cronbach Alpha lebih besar dari 0,7.

\section{Deskripsi Hasil Penelitian}

\section{Orientasi Etika}

Total rata-rata untuk variabel $X$, yaitu orientasi etika sebesar 71,5, sehingga dapat disimpulkan bahwa orientasi etika masuk dalam kategori baik yang berkisar antara 68-83.99.

\section{Komitmen Profesional}

Total rata-rata untuk variabel Y yakni komitmen professional sebesar 71,7, sehingga dapat disimpulkan bahwa komitmen professional masuk dalam kategori atau rentang baik yang berkisar antara 68-83.99.

3. Kualitas Audit

Total rata-rata untuk variabel $\mathrm{Z}$ yakni kualitas audit sebesar 72,3. Sehingga dapat disimpulkan bahwa auditor telah memiliki kemampuan dalam menemukan dan melaporkan pelanggaran yang ada dalam sistem akuntansi klien.

\section{Pengujian Hipotesis dan Pembahasan}

\section{Pengaruh Orientasi Etika Terhadap Komitmen Profesional}

Untuk menganalisa data digunakan software SPSS 19.0 for Windows, hasil pengujian (output SPSS) disajikan sebagai berikut :

\section{Tabel 1. Pengaruh $\mathrm{X}$ terhadap $\mathrm{Y}$}

\begin{tabular}{|c|c|c|c|c|c|c|}
\hline No & \multicolumn{2}{|c|}{$\begin{array}{c}\text { Koefisien } \\
\text { Jalur }\end{array}$} & $\begin{array}{c}\mathbf{t} \\
\text { hitung }\end{array}$ & t & Keputusan & Kesimpulan \\
\hline 1 & $\rho y_{x}$ & 0,507 & 4,078 & 1,980 & Ho ditolak & Signifikan \\
\hline
\end{tabular}

Berdasarkan tabel 1 diperoleh nilai statsitik uji pengaruh orientasi etika terhadap komitmen profesional menghasilkan nilai thitung sebesar 4,078. Selanjutnya nilai tersebut akan dibandingkan dengan nilai t dari tabel. Dari tabel t dengan tingkat signifikansi (0.05) dan derajat bebas 50 diperoleh nilai thitung sebesar 1,980. Karena thitung (4,078 lebih besar dibanding ttabel $(1,980)$ maka pada tingkat kekeliruan $5 \%$ ada alasan yang kuat untuk menolak H0 dan menerima hipotesis penelitian (H1), sehingga dapat disimpulkan bahwa orientasi etika berpengaruh terhadap komitmen profesional.

Berdasarkan hasil analisis deskriptif menunjukkan bahwa auditor BPK RI Jawa Barat secara keseluruhan telah memiliki tingkat orientasi etika yang baik, artinya auditor BPK RI Jawa Barat memiliki kemampuan untuk mengenali sifat etis sesuai dengan apa yang dikemukakan oleh Forsyth (1980), yaitu bahwa orientasi etika digerakkan oleh dua karakteristik yaitu idealisme dan relativisme. Seorang auditor yang memiliki orientasi etika lebih tinggi cenderung untuk dapat mengenali isu-isu etika dengan lebih teliti, membuat keputusan yang menyangkut etika dengan lebih baik, lebih berhati-hati ketika menghadapi dilema etika, berusaha menerapkan standar profesi lebih konsisten dan terakhir adalah melakukan pekerjaan profesionalnya dengan objektif. 
Hal tersebut sesuai dengan teori yang dikemukakan oleh Oleh karena itu, orientasi etika memiliki dampak positif terhadap komitmen profesional.

\section{Pengaruh Orientasi Etika Terhadap Kualitas Audit}

Tabel 2. Pengaruh $X$ terhadap $Z$

\begin{tabular}{|c|c|c|c|c|c|c|}
\hline No & \multicolumn{2}{|c|}{$\begin{array}{c}\text { Koefisien } \\
\text { Jalur }\end{array}$} & $\begin{array}{c}\mathbf{t} \\
\text { hitung }\end{array}$ & $\mathbf{t}$ & Keputusan & Kesimpulan \\
\hline 1 & $\rho z_{\mathrm{x}}$ & 0,543 & 4,310 & 1,980 & $\mathrm{H}_{0}$ ditolak & Signifikan \\
\hline
\end{tabular}

Berdasarkan tabel 2 diperoleh nilai statsitik uji pengaruh orientasi etika terhadap kualitas audit menghasilkan nilai thitung sebesar 4,310. Selanjutnya nilai tersebut akan dibandingkan dengan nilai $t$ dari tabel. Dari tabel t dengan tingkat signifikansi (0.05) dan derajat bebas 50 diperoleh nilai thitung sebesar 1,980. Karena thitung $(4,310)$ lebih besar dibanding ttabel $(1,980)$ maka pada tingkat kekeliruan 5\% ada alasan yang kuat untuk menolak H0 dan menerima hipotesis penelitian (H1), sehingga dapat disimpulkan bahwa orientasi etika berpengaruh terhadap kualitas audit.

Berdasarkan hasil analisis deskriptif menunjukkan bahwa auditor BPK RI Jawa Barat secara keseluruhan telah memiliki tingkat orientasi etika yang baik. Seperti yang dikemukakan oleh Arens (2008:98) bahwa etika secara garis besar dapat di definisikan sebagai serangkaian prinsip atau nilai moral. Orientasi etika telah menjadi salah satu pendorong utama untuk menciptakan kode etik khusus yang membatasi profesi dan masyarakat dalam menentukan tingkat kualitas pekerjaan. Auditor yang memiliki orientasi etika akan mempengaruhi profesi, kredibilitas, pemasaran dan efektivitas. Dengan demikian, semakin besar orientasi etika yang dimiliki oleh auditor maka semakin tinggi pula kualitas audit yang akan didapatkan. Oleh karena itu, orientasi etika memiliki dampak positif terhadap kualitas audit.

\section{Pengaruh Komitmen Profesional Terhadap Kualitas Audit}

Tabel 3. Pengaruh Y terhadap $Z$

\begin{tabular}{|c|c|c|c|c|c|c|}
\hline No & \multicolumn{2}{|c|}{$\begin{array}{c}\text { Koefisien } \\
\text { Jalur }\end{array}$} & $\begin{array}{c}\mathrm{t} \\
\text { hitung }\end{array}$ & $\begin{array}{c}\mathbf{t} \\
\text { tabel }\end{array}$ & Keputusan & Kesimpulan \\
\hline 1 & $\rho z_{y}$ & 0,527 & 4,299 & 1,980 & $\mathrm{H}_{0}$ ditolak & Signifikan \\
\hline
\end{tabular}

Berdasarkan tabel 3 diperoleh nilai statsitik uji pengaruh komitmen profesional terhadap kualitas audit menghasilkan nilai thitung sebesar 4,299. Selanjutnya nilai tersebut akan dibandingkan dengan nilai t dari tabel. Dari tabel t dengan tingkat signifikansi (0.05) dan derajat bebas 50 diperoleh nilai thitung sebesar 1,980. Karena thitung $(4,299)$ lebih besar dibanding ttabel $(1,980)$ maka pada tingkat kekeliruan $5 \%$ ada alasan yang kuat untuk menolak H0 dan menerima hipotesis penelitian (H1), sehingga dapat disimpulkan bahwa komitmen profesional berpengaruh terhadap kualitas audit. 
Hasil analisis deskriptif menunjukkan bahwa auditor BPK RI Jawa Barat telah menunjukkan komitmen professional yang tinggi dalam menjalankan pekerjaannya dan dengan komitmen profesional yang tinggi cenderung menghasilkan manfaat dan keuntungan bagi dirinya sendiri dan lembaga profesionalnya. Sesuai dengan yang dikemukakan oleh Aranya dan Ferish (1984) bahwa komitmen profesional mempunyai karakteristik sebagai berikut: 1.) Identifikasi, 2.) Keterlibatan, 3.) Loyalitas. Komitmen profesional diterapkan dalam rangka meningkatkan kualitas audit di pasar audit dan lingkungan yang kompetitif. Oleh karena itu, komitmen profesional memiliki dampak positif terhadap kualitas audit.

\section{Pengaruh Orientasi Etika Terhadap Komitmen Profesional dan Implikasinya pada Kualitas Audit}



Gambar 1. Diagram Jalur Pengaruh Orientasi Etika Terhadap Komitmen Profesional dan Implikasinya pada Kualitas Audit

Melalui diagram jalur tersebut di atas, maka dapat dijelaskan bahwa orientasi etika dapat berpengaruh langsung terhadap kualitas audit dan dapat juga berpengaruh tidak langsung yaitu dari orientasi etika ke komitmen professional sebagai intervening lalu kepada kualitas audit. Besarnya pengaruh langsung dan tidak langsung dapat dijelaskan sebagai berikut:

a. Pengaruh langsung orientasi etika terhadap kualitas audit adalah $=(0,351) \times(0,351)=0,123$ $(12,3 \%)$.

b. Pengaruh tidak langsung orientasi etika terhadap kualitas audit melalui komitmen profesional adalah $=(0,351) \times(0,507) \times(0,349)=0,062(6,2 \%)$

c. Pengaruh total orientasi etika terhadap kualitas audit adalah $=0,123+0,062=0,185(18,5 \%)$

Hasil penelitian membuktikan bahwa orientasi etika memiliki korelasi yang positif terhadap komitmen professional dengan tingkat keeratan hubungan yang sedang. Orientasi etika juga memiliki hubungan yang sedang dengan kualitas audit. Sedangkan hubungan antara komitmen professional dengan kualitas audit berada pada rentang sedang. Adapun pengaruh langsung orientasi etika terhadap kualitas audit lebih besar dibandingkan pengaruh tidak langsungnya melalui komitmen profesional. 


\section{Kesimpulan}

1. Orientasi etika berpengaruh positif terhadap komitmen profesional, sehingga semakin baik tingkat orientasi etika yang ditunjukkan oleh auditor, maka akan semakin tinggi komitmen pada profesinya

2. Orientasi etika berpengaruh positif terhadap kualitas audit, sehingga semakin baik tingkat orientasi etika yang ditunjukkan oleh auditor, maka akan semakin baik kualitas kualitas audit yang dilakukannya.

3. Komitmen profesional berpengaruh positif terhadap kualitas audit, sehingga semakin baik komitmen profesional seorang auditor, maka akan semakin baik kualitas kualitas audit yang dilakukannya.

4. Orientasi etika berpengaruh positif terhadap komitmen profesional dan memiliki implikasi pada kualitas audit. Besarnya pengaruh langsung orientasi etika terhadap kualitas audit adalah $12,3 \%$ dan pengaruh tidak langsung orientasi etika terhadap kualitas audit melalui komitmen profesional adalah $6,2 \%$.

\section{Saran}

Bagi penelitian selanjutnya, peneliti menyarankan untuk;

1. Menambah variable lainnya seperti kompetensi dan independensi untuk meneliti faktor-faktor yang mempengaruhi kualitas audit.

2. Memperluas pengambilan sampel.

\section{Daftar Pustaka}

Alim, M.N.; Hapsari, T.; dan Purwanti, L., Pengaruh Kompetensi dan Independensi terhadap Kualitas Audit dengan Etika Auditor Sebagai Variabel Moderasi, Simposium Nasional Akuntansi X, Unhas Makassar, 26-28 Juli 2007.

Alwi Hasan, dkk. 2005. Kamus Besar Bahasa Indonesia. Jakarta : Departemen Pendidikan Nasional Balai Pustaka.

Aranya N, and K. R Ferris. 1984. "A Reexamination of Accountant Organizational-Profesional Conflic”. The Acounting Review. 59 pp 1-15

Arens, Alvin A., et.al.(2008). Auditing dan Jasa Assurance (Pendekatan Terintegrasi) Jilid I.Erlangga: Jakarta.

Arens, Alvin A. Et.al.(2010). Auditing and Assurance Services and ACL Software. 13 th Edition. New Jersey : Prentice Hall.

Arikunto, Suharsimi. 2002. Prosedur Penelitian : Suatu Pendekatan Praktek. Edisi Revisi IV, Jakarta : Rineka Cipta.

Association of Certified Fraud Examiners (ACFE). 2012. Report To The Nations on Occupational Fraud and Abuse.

Basuki dan Krisna, Y. Mahardani. 2006. "Pengaruh Tekanan Anggaran Waktu terhadap Perilaku Disfungsional Auditor dan Kualitas Audit pada Kantor Akuntan Publik di Surabaya." Jurnal Manajemen Akuntansi \& Sistem Informasi MAKSI UNDIP (Agustus): vol. 6, No. (2), 177-256. 
Boynton, W.C., R.N. Johnson, dan W.G. Kell, 2002, Modern Auditing 7th Edition, New York; John Wiley and Sons, Inc.

Christiawan, Y.J. 2002. "Kompetensi dan Independensi Akuntan Publik: Refleksi Hasil Penelitian Empiris”. Journal Directory: Kumpulan Jurnal Akuntansi dan Keuangan Unika Petra. Vol. 4 / No. 2.

Clikeman, Paul M., Schwartz, Bill N. and Lathan, Malcolm H. 2001. The Effect of the 150-Hour Requirement on New Accountants' Professional Commitment, Ethical Orientation, and Professionalism. Critical Perspectives on Accounting, 12: 627-645.

Damodar, Gujarati, 2001, Ekonometrika Dasar, Alih Bahasa Sumarno Zain, Erlangga, Jakarta.

De Angelo, L., 1981, Auditor Size and Audit Quality, Journal of Accounting and Economics, July., 184-197.

Elfarini, Eunike Christina. 2007. Pengaruh Kompetensi dan Independensi Auditor terhadap Kualitas Audit. Skripsi. Universitas Negeri Semarang.

Finn, D.W., L.B Chonko, and J.D Hunt. 1988. "Ethical Problem in Public Accounting: The View from The Top". Journal of Bussiness Ethics, 7, pp. 605-615

Forsyth, D.R. 1980. "A Taxonomy of Ethical Ideology”, Journal of Personality and Social Psychology, Vol. 39, pp. 175-184.

Forsyth, D.R. 1981. “Moral Judgment: The Influence of Ethical Ideology” Personality and Social Psychology Bulletin, Vol. 7, pp. 218-223.

Ghozali, Imam. 2005. Aplikasi Analisis Multivariate dengan Program SPSS. Edisi 3. Badan Penerbit Universitas Diponegoro. Semarang.

Hidayat, Dikdik. 2003. “Opini "Disclaimer" BPK atas LKPP Kurang Profesional”. Copyright () Sinar Harapan.

Husein Umar, Metode Penelitian Untuk Skripsi dan tesis Bisnis, (2008), Jakarta : PT. Raja Grafindo Persada.

Ikatan Akuntansi Indonesia-Kompartemen Akuntan Publik (IAI-KAP).(2011). Standar Profesional Akuntan Publik. Salemba Empat : Jakarta.

Indriantoro, Nur. Dan Supomo, Bambang. 2002. Metodologi Penelitian Bisnis. Catatan Kedua, Yogyakarta: Penerbit BFFE UGM.

Kusharyanti. 2003. "Temuan penelitian mengenai kualitas audit dan kemungkinan topik penelitian di masa datang”. Jurnal Akuntansi dan Manajemen (Desember). Hal.25-60.

Larkin, Joseph M (1990). “Does Gender Affect Auditor KAPs' Performance?”, The Woman CPA. Spring pp. 20-24.

Mardiasmo, 2005. Akuntansi Sektor Publik Edisi 2. Penerbit Andi. Yogyakarta.

Mardisar. D dan R. Nelly Sari. 2007. Pengaruh Akuntabilitas dan Pengetahuan terhadap Kualitas Hasil Kerja Auditor. SNA X Makassar.

Messier, F.W., V.S. Glover, dan F.D. Prawitt. 2005. Jasa Audit dan Assurance: Suatu Pendekatan Sistematis. Diterjemahkan oleh Nuri Hinduan. Edisi 4 Buku 1 \& 2. Penerbit Salemba Empat. Jakarta.

Mowday, R. T., L. W Porter dan R. M. Steers. 1982. Employee-Organization Linkages. New York: Academic Press. 
Mulyadi. 2002. Auditing. Edisi Keenam. Buku 1. Jakarta: Salemba Empat.

Narkubo, Cholid. (2005). Metodelogi Penelitian. Jakarta : bumi Aksara.

Nurfarida, Lia 2011. Pengaruh Budaya Etis Organisasi dan Orientasi Etika Terhadap Komitmen Organisasi dan Sensitivitas Etika Auditor. Skripsi. FE. Universitas Islam Negeri Jakarta.

Ponemon, Lawrence A. "Ethical Reasoning and Selection-Socialization in Accounting." Accounting, Organization and Society, March 1992, 239-234.

Priyatno, Duwi. 2010. Teknik Mudah dan Cepat Melakukan Analisis Data Penelitian Dengan SPSS. Yogyakarta : Gava Media.

Purba. J. M. \& Pujiastuti. S. E. (2009). Dilema Etik \& Pengambilan Keputusan Etis. Jakarta. EGC.

Rest, J. R. \& Narvaez, D. (1994). Moral Development in Professions. New Jersey: Lawrence Erlbaum Associates Pub.

S.Y.Lu, W. Elmaraghy, A.Schuh, dan R.Wilhelm. 2007. "A Scientific Foundation of Collaborative Engineering CIRP Annals". Manufacturing Technology.

Samelson, D., Lowenshon, S., and Johnson, L. 2006. The Determinants of Perceived Audit Quality and Auditee Satisfaction in Local Goverenment. Journal of Public Budgeting, Accounting \& Financial Management, Vol. 18, No. 2.

Schawrtz Felice. N. 1996. Women in the Profession. Journal of Accountancy. February. Pp. 3942.

Sitanggang, Abdonsius. 2007. "Penerimaan Auditor terhadap Perilaku Audit Disfungsional: Suatu Model Penjelasan dengan Menggunakan Karakteristik Personal Auditor (Studi Empiris pada Kantor Akuntan Publik di DKI Jakarta)". Semarang: UNDIP.

Sososutikno, C. 2003. Hubungan Tekanan Anggaran Waktu dengan Perilaku Disfungsional serta Pengaruhnya terhadap kualitas Audit. Simposium Nasional Akuntansi VI. Surabaya.

Sugiyono, (2010), Metode Penelitian Bisnis. Bandung: Alfabeta.

Sukrisno Agoes. (2004). Auditing (Pemeriksaan Akuntan) oleh Kantor Akuntan Publik. Edisi Ketiga. Penerbit Fakultas Ekonomi Universitas Trisakti.

Suryadi dan Purwanto, (2009), Statistika Untuk Ekonomi dan Keuangan Modern, Jakarta: Salemba Empat.

Tuanakotta, Theodorus M. 2007. Akuntansi Forensik dan Audit Investigatif. Lembaga Penerbit Fakultas Ekonomi Universitas Indonesia.

Ludigdo U dan Machfoedz M. 1999. "Persepesi Akuntan dan Mahasiswa terhadap Etika Bisnis". Jurnal Riset Akuntanis Indonesia. IAI. Vol.2 No. 1 Januari hal 1- 19.

Wang, X., dan Anona Armstrong. "A Structural Model of Professional Commitment from the Perspective of Characteristics of a Professional Community." Working Paper School of Management, Victoria University of Technology, 2001.

Wibowo, Purwoko. 1996. Analisis Pengaruh Pengalaman terhadap Profesionalisme Auditor Internal dan Pengaruh Profesionalieme terhadap Komitmen Organisasional, Dorongan Berpindah Kerja, Kepuasan Kerja dan Kinerja Auditor Internal, FE UGM.

Widarjono, Agus (2005), Ekonometrika: Teori dan Aplikasi, Yogyakarta: Ekonisia. 
Wooten, T.G. 2003. It is Impossible to Know The Number of Poor-Quality Audits that simply go undetected and unpublicized. The CPA Journal. Januari. pp. 48-51.

http://www.adeksi.or.id

http://www.Lensaindonesia.com

http://politik.news.viva.co.id/news/read/161408-kpk-tetapkan-lagi-auditor-bpk-jadi-tersangka 